Major Ing. Bohuslav Sotulář

Výpočet vzdáleností objektu

od výstřelné roviny pro kontrolu

bezpečnosti střelby

hlavňového dělostřelectva

\title{
Calculation of the Distance of the Object from Plane of Fire to Control Check the Barrel Artillery Fire Safety
}

\section{Abstrakt:}

Cílem článku je objasnit možnost výpočtu kolmé vzdálenosti objektu (pozorovatelny, budov atd.), od výstřelné hlavňového dělostřelectva. Postup výpočtu neni uveden $v$ žádném z předpisů rešíci problematiku bezpečnosti při střelbě hlavňového dělostřlectva.

Článek řšsi matematické zdůvodnění a výpočty, které jsou využitelné pro štáby dělostřeleckých jednotek pri připravě a plánováni bojových střeleb. Odvozené vzorce lze využit palebnými rozhodčimi při kontrole bezpečnosti střlby.

\section{Abstract:}

This article aims to explain the possibility of calculating the perpendicular distance of object (observation, building etc.) from the barrel of fire artillery. The advancement calculation is not included in any legislation addressing the issue of fire safety in the barrel artillery.

This paper discusses the mathematical reasoning and calculations that are useful in the preparation of documentation for shooting in the time preparation of shootings. The derived formula can be used by judges when firing safety control shooting.

\section{Klíčová slova:}

Bezpečnost, kolmá vzdálenost, výstřelná rovina, pozorovatelna, dělo, cíl, objekt.

Key words:

Safety, perpendicular distance, plane of fire, observation, cannon, target, object. 


\section{Úvod}

Při střelbách hlavňového dělostřelectva je třeba dodržovat bezpečnostní opatření uváděná v předpise Vševojsk 2-9 Bezpečnostní opatření při výcviku, definující určení bezpečnostních vzdáleností:

a) bezpečná vzdálenost $\mathrm{Bv}[\mathrm{m}]$ (níže definovaná jako vzdálenost mezi objektem a cílem)

b) bezpečná vzdálenosti mezi objekty a výstřelnou rovinou

Tento článek se zaobírá prioritně určením (výpočtem) bezpečné vzdálenosti mezi objekty a výstřelnou rovinou.

Bezpečnostní opatření se týkají všech objektů, které mohou být ohroženy střelbou. $\mathrm{K}$ těmto objektům patří nekryté cvičící jednotky, jednotky v obrněné technice, místa velení, sklady, obydlená místa, apod. Patří sem i pozorovací stanoviště, která nejsou při střelbě přestřelována.

Hodnoty uvedené v předpise též rozlišují, zda střelba je př́má nebo nepř́ímá.

Pro dodržování bezpečnostních opatření v souladu s předpisem V̌̌evojsk 2-9 při střelbě hlavňového dělostřelectva je třeba znát:

a) vzdálenosti mezi objektem a cílem nebo elementárními cíli, na které bude vedena palba,

b) nejmenší vzdálenost mezi objektem a výstřelnou rovinou.

Zjištěné hodnoty se porovnávají s př́ípustnými hodnotami, které jsou uvedené v předpise Vševojsk 2-9 a jsou závislé na typu objektu a stupni jeho krytí, ale i na druhu střelby (př́má, neprímá).

$\mathrm{V}$ rámci př́ípravy a plánování bojových střeleb dělostřelectva je prioritním úkolem volba rozmístění bojové sestavy dělostřeleckých jednotek a terčového manévru. $Z$ tohoto pohledu do bojové sestavy řadíme palebná postavení jednotek dělostřelectva a prostory rozmístění pozorovatelen. Terčový manévr je volen tak aby zabezpečil udržení bezpečnostních vzdáleností definovaných předpisem Vševojsk 2-9.

Při provádění plánování cvičení jednotek dělostřelectva (minometných jednotek) je součástí toho to procesu výběr jednotlivých palebných postavení (palebná stanoviště ř́dících děl) a poloh cílů (v prostorech cílových ploch vojenských újezdu), na které se plánuje provádění palby děl a minometů.

Zakreslí se poloha objektů, které mohou být ohroženy palbou a následně se zakreslí jednotlivé palby v souladu se záměrem cvičení. Pro kontrolu bezpečnosti střelby se vyberou objekty, které jsou výstřelné rovině nejblíže. [1]

Vstupními informacemi při určování bezpečných vzdáleností jsou souřadnice (jsou uvedeny $\mathrm{N} \mathrm{a} \mathrm{E}$ ) těchto bodů:

- Baterie $\left(\mathrm{N}_{\mathrm{B}}, \mathrm{E}_{\mathrm{B}}\right)$ - palebné postavení děla baterie (ř́dící děla baterií, čet);

- Cíl $\left(\mathrm{N}_{\mathrm{C}}, \mathrm{E}_{\mathrm{C}}\right) \quad$ - cíl;

- Objekt $\left(\mathrm{N}_{\mathrm{P}}, \mathrm{E}_{\mathrm{P}}\right)$ - objekt (nekryté cvičící jednotky, jednotky v obrněné technice, místa velení, sklady, obydlená místa, případně pozorovatelna ...).

Baterie - označen „B“

Cíl - označen „C“

Objekt - označen „P“ 


\section{Zpưsoby určení vzdálenosti mezi objektem a cílem}

Určení vzdálenosti mezi objektem a cílem je možné provést následujícími způsoby:

a) Změřením dálkoměrem - lze provést při přípravě cvičení v rámci rekognoskace terénu určeného pro výcvik. Při přípravě cvičení musí být předem určeny souřadnice objektu a souřadnice cíle. Tyto souřadnice nemohou být měněny.

b) Graficky - vynesením bodu objektu a bodu cíle do mapy s následným změřením vzdálenosti na mapě a přepočítáním podle měřítka mapy na skutečnou vzdálenost.

c) Výpočtem - vzdálenosti mezi objektem a cílem (definovanou jako $d_{C}$ ) se vypočte pomocí souřadnicových rozdílů a Pythagorovy věty.

Ad c) Výpočet souřadnicových rozdílů $\Delta N_{(P-C)}$ a $\Delta E_{(P-C)}$ v osách $N$ a $E$ mezi cílem C a objektem P:

$$
\begin{aligned}
& \Delta N_{(P-C)}=N_{C}-N_{P}, \\
& \Delta E_{(P-C)}=E_{C}-E_{P},
\end{aligned}
$$

Výpočet vzdálenosti $d_{C}$ mezi cílem $\mathrm{C}$ a objektem $\mathrm{P}$ se vypočte pomocí souřadnicových rozdílů (1) a (2) a Pythagorovy věty

$$
d_{C}=\sqrt{\left(\Delta N_{(P-C)}\right)^{2}+\left(\Delta E_{(P-C)}\right)^{2}} .
$$

\section{Dílčí závěr}

Jedna z podmínek bezpečnosti provádění bojových střeleb je určení bezpečné vzdálenosti $\mathrm{Bv}[\mathrm{m}]$ mezi objektem a cílem. Tato vzdálenost se porovnává s př́pustnou hodnotou, jejíž výpočet je uveden v předpise Vševojsk 2-9, čl. 54. Vzhledem k tomu, že vzdálenost mezi objektem a cílem je zjistitelná, není problém při nevyhovění normy změnit palebné postavení, nebo přidělit palebný úkol jiné jednotce, u které bezpečná vzdálenost vyhovuje. Další možností je, pokud podmínky dovolí, přesunout objekt (pojízdný sklad, velitelské stanoviště, obrněnou techniku, živou sílu, pozorovatelnu .... ) na jiné výhodnější místo.

\section{Způsob určení nejmenší vzdálenosti mezi objektem a výstřelnou rovinou}

Určení vzdálenosti mezi objektem a výstřelnou rovinou není možné provést měřením v terénu. Úlohu je možno řešit následujícími metodami:

a) Grafickou metodou. Při této metodě se zakreslí do mapy body palebného postavení děl a body cíle. Vynesením jejich spojnice dělo - cíl se vytvoří výstřelná rovina. Dále se zakreslí objekt (např́iklad místo velení) a kolmice k výstřelné rovině tak, že prochází objektem. Změří se délka této kolmice a podle měřítka mapy se přepočítá na skutečnou vzdálenost. 
b) Početní metodou. Tato úloha je poněkud složitější, protože není uveden možný způsob výpočtu $\mathrm{v}$ žádném předpise, minimální vzdálenosti mezi objektem a výstřelnou rovinou. Cílem tohoto článku je rozebrat jeden z možných způsobů výpočtu.

\subsection{Grafická metoda}

Řešení minimální vzdálenosti mezi objektem a výstřelnou rovinou je zatíženo chybou zákresů do mapy a chybou měření vzdálenosti na mapě. Tyto jednotlivé chyby mohou činit až $0,5 \mathrm{~mm} v$ měřítku mapy.

Chyby v měřítku mapy mohou být následující:

- $0,5 \mathrm{~mm}$ při vynesení spojnice „palebné postavení - cíl“ (výstřelná rovina) v kolmém směru na bod objektu,

- $0,5 \mathrm{~mm}$ při vynesení bodu objektu v kolmém směru na spojnici př́ímky „palebné postavení - cíl“" (výstřelnou rovinu),

- $0,5 \mathrm{~mm}$ při změření délky kolmice mezi bodem objektu a průsečíkem kolmice s př́mkou „palebné postavení - cíl“" (výstřelnou rovinou).

Vyskytnou-li se tyto chyby v nejméně příznivém př́ípadě, pak celková chyba může dosáhnout součtu všech těchto chyb a dosáhne až $1,5 \mathrm{~mm}$ v měřítku mapy. $V$ tabulce jsou uvedeny závislosti mezi měřítkem mapy a chybou v terénu při chybě $1,5 \mathrm{~mm}$ měř́tka mapy.

Pro př́iklad je uvedena délka úsečky na mapě odpovídající maximální možné dálce střelby dělostřelectva AČR, což je $20 \mathrm{~km}$.

Tab.: Velikost chyby $1,5 \mathrm{~mm}$ v měřítku mapy

\begin{tabular}{|c|c|c|}
\hline Měřítko mapy & $\begin{array}{c}\text { Délka úsečky v [cm] } \\
\text { pro zákres 20km dálky střelby }\end{array}$ & $\begin{array}{c}\text { Chyba 1,5mm v měřítku mapy } \\
\text { je ve skutečnosti chyba v }[\mathbf{m}]\end{array}$ \\
\hline $1: 100000$ & 20 & 150 \\
\hline $1: 50000$ & 40 & 75 \\
\hline $1: 25000$ & 80 & 37,5 \\
\hline $1: 10000$ & 200 & 15 \\
\hline $1: 5000$ & 400 & 7,5 \\
\hline
\end{tabular}

Zdroj: vlastní

\section{Závěr z grafického řešení minimální vzdálenosti pozorovatelny od výstř̌elné}

Pro předpokládanou dálku střelby $20 \mathrm{~km}$, při vynesení spojnice palebné postavení - cíl do mapy měř́tka 1:100 000 (nebo případně 1:50 000) odpovídá délka úsečky $20 \mathrm{~cm}$ (př́ípadně $40 \mathrm{~cm}$ ). Chyba vynesení bodů a následné změření vzdálenosti od roviny výstř̌elné $\mathrm{k}$ objektu při této metodě měření v nejméně př́iznivém případě dosáhne $150 \mathrm{~m}$ (nebo př́padně $75 \mathrm{~m}$ ).

Při použití přesnějších měřítek 1:25 000 (prrípadně 1:10 000) bude celková chyba v nejméně př́znivém př́ípadě dosahovat $37,5 \mathrm{~m}$ (případně $15 \mathrm{~m}$ ).

Pokud bude střelba vedena na kratší dálku, lze volit menší měřítko mapy, a tím se chyba v měřítku mapy úměrně sníží. 
Pro malé dálky střelby nap̌r. 3 km a měřítku mapy 1:5 000 celková chyba v nejméně př́znivém př́ípadě dosáhne $7,5 \mathrm{~m}$.

Z uvedeného vyplývá, že pro velké dálky střelby je přesnější řešit vzdálenost mezi objektem a výstřelnou rovinou početním způsobem. Pro malé dálky střelby je jednodušší a rychlejší řešit úlohu graficky.

Je třeba si uvědomit, že běžně dělostřelci pracují s mapami v měřítku 1:50 000, př́ípadně v měřítku 1:25 000.

\subsection{Početní metoda - Metoda prưsečíku přímky a kružnice}

Při výběru početní metody byl zvolen způsob výpočtu, který vyžaduje minimum pomocných výpočtů. Tomu vyhovuje vytvořený způsob výpočtu metodou průsečíku př́mky a kružnice, jak je uvedeno na obr.

\section{Princip řešení}

Hledáme nejmenší poloměr kružnice $\mathrm{R}$, která se dotýká výstřelné roviny v jednom bodě (výstřelná je tečnou kružnice).

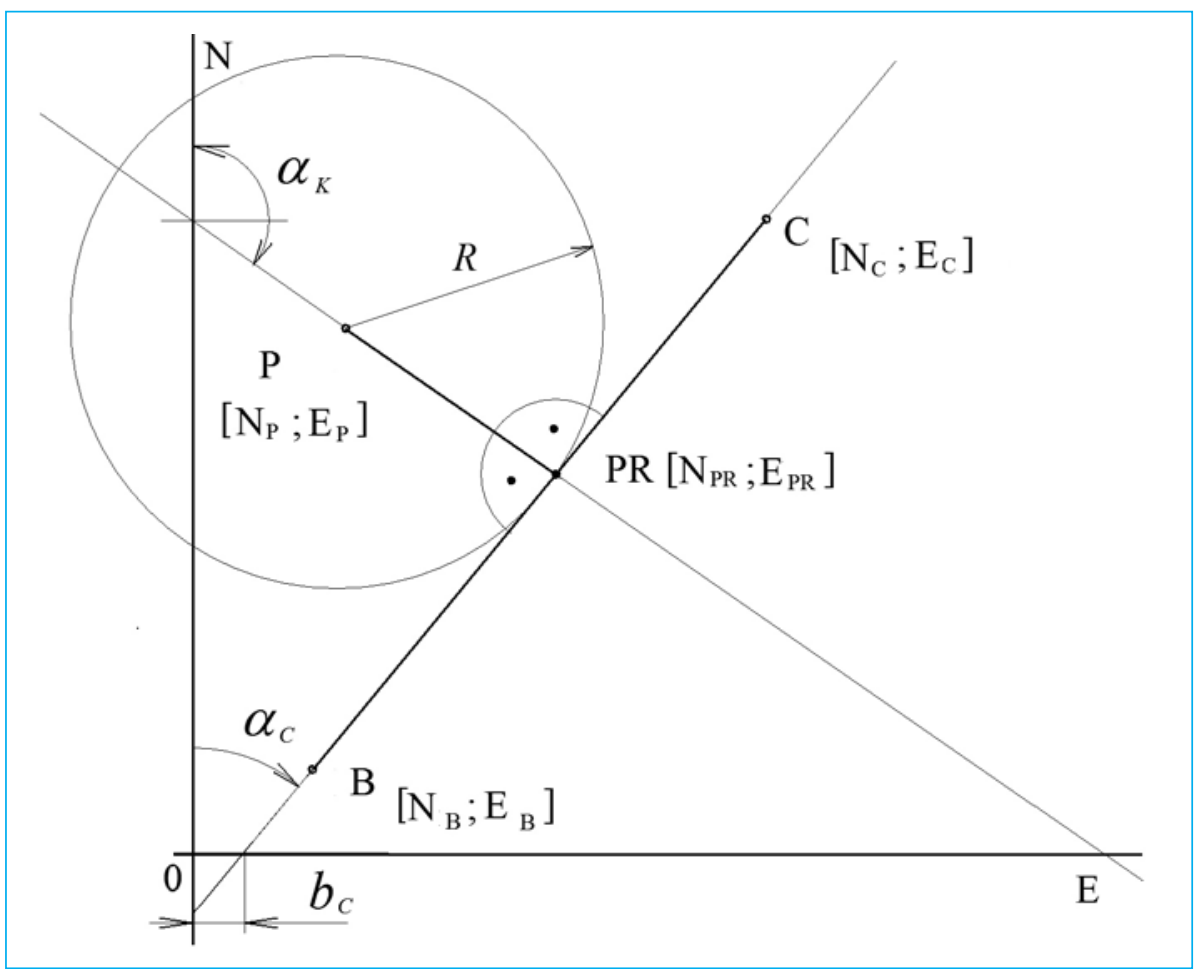

Zdroj: vlastní

Obr.: Průsečík kružnice s prímkou 


\section{Legenda:}

$\mathrm{R}-$ - nejmenší vzdálenost mezi pozorovatelnou a výstřelnou rovinou

$\mathrm{B}\left(\mathrm{N}_{\mathrm{B}}, \mathrm{E}_{\mathrm{B}}\right) \quad$ - souřadnice palebného postavení děla

$\mathrm{C}\left(\mathrm{N}_{\mathrm{C}}, \mathrm{E}_{\mathrm{C}}\right)$ - souřadnice cíle

$\mathrm{P}\left(\mathrm{N}_{\mathrm{P}}, \mathrm{E}_{\mathrm{P}}\right) \quad$ - souřadnice objektu (napríklad pozorovatelny)

$\mathrm{PR}\left(\mathrm{N}_{\mathrm{PR}}, \mathrm{E}_{\mathrm{PR}}\right)$ - souřadnice průsečíku výstřelné roviny a kolmice procházející pozorovatelnou

$\mathrm{b}_{\mathrm{C}} \quad-$ posunutí prímky výstřelné roviny oproti počátku souřadnic na ose $\mathrm{E}$

$\alpha_{C} \quad-$ směrník na cíl z palebného postavení děla

$\alpha_{\mathrm{K}}-$ směrník kolmice na výstřelnou rovinu

Nejprve definujeme rovnici kružnice s počátkem $\mathrm{v}$ bodě $\mathrm{P}\left(\mathrm{N}_{\mathrm{p}}, \mathrm{E}_{\mathrm{P}}\right)$ a o poloměru R:

$$
\left(E-E_{P}\right)^{2}+\left(N-N_{P}\right)^{2}=R^{2} .
$$

Rovnice př́mky výstř̌elné, která prochází body B (palebné postavení děla) a C (cíl) je definována

$$
E=a_{C} \cdot N+b_{C},
$$

kde směrnice př́ímky výstřelné roviny (směrník na cíl z palebného postavení děla) má tvar:

$$
a_{C}=\operatorname{tg} \alpha_{C}=\frac{\Delta E_{(B-C)}}{\Delta N_{(B-C)}}=\frac{E_{C}-E_{B}}{N_{C}-N_{B}} .
$$

Nachází-li se bod C (cíl) na př́mce výstř̌elné roviny, pak po dosazení jeho souřadnic do rovnice (5) bude tvar rovnice

$$
E_{\mathrm{C}}=a_{C} \cdot N_{C}+b_{C} .
$$

Po úpravě rovnice (7) je posunutí prrímky

$$
b_{C}=E_{\mathrm{C}}-a_{C} \cdot N_{\mathrm{C}} .
$$

\section{Kontrola výpočtu posunutí prrímky}

Protože bod $\mathrm{B}$ (palebné postavení) a C (cíl) se bude vždy nacházet na přímce výstřelné roviny, po dosazení souřadnic palebného postavení do rovnice (5), rovnice přejde do tvaru

$$
E_{\text {B }}=a_{C} \cdot N_{B}+b_{B} .
$$

Po úpravě, posunutí př́ímky je

$$
b_{B}=E_{\mathrm{B}}-a_{C} \cdot N_{\mathrm{B}} .
$$

Jelikož jsou oba body B (palebné postavení) a C (cíl) na stejné př́mce, musí platit, že rovnice (8) a (10) se sobě rovnají. Proto platí

$$
b_{B}=b_{C} .
$$

Tím je zkontrolována správnost výpočtu parametrů $a_{C}$ a $b_{B}$ a tím i $b_{C}$. 
Jsou již definovány dvě rovnice, a to:

- rovnice př́mky (5),

- rovnice kružnice (4).

Na první pohled se jeví, že nejjednodušší je vypočítat souřadnice $\left(\mathrm{N}_{\mathrm{PR}}, \mathrm{E}_{\mathrm{PR}}\right)$ bodu $\mathrm{PR}$, tedy průsečík obou rovnic. Úloha však není přímo obecně řešitelná, protože není známý poloměr R, což je vzdálenost objektu P od výstřelné roviny.

Jsou tedy 3 neznámé $\mathrm{N}_{\mathrm{PR}}, \mathrm{E}_{\mathrm{PR}}$, $\mathrm{R}$ a jen 2 rovnice (rovnice př́mky, rovnice kružnice).

Řešení je možné:

- numericky - iterační metodou, nebo

- pomocí extrému funkce.

\subsubsection{Iterační metoda}

Tato metoda spočívá v opakovaném odhadu poloměru $\mathrm{R}$ a výpočtu průsečíků kružnice na přímce. Poloměr R se z počátku zvolí velmi velký a následně se zmenšuje pro každý další odhad. Oba průsečíky kružnice na př́ímce se k sobě přibližují se zmenšujícím se poloměrem R. Výpočet je ukončen, když se oba průsečíky spojí v jeden „dvojný bod“, což odpovídá průsečíku (dotyku) přímky s kružnicí. Pro výrazné snížení počtu iterací výpočet můžeme považovat ukončen, když při odhadu poloměru R je vypočtená vzdálenost průsečíků menší přípustná hodnota. Tuto hodnotu je vhodné volit proměnlivou v závislosti na R. Mezní maximální vzdálenost průsečíků kružnice s přímkou doporučuji volit $0,01 \cdot R, \mathrm{kdy}$ chyba odhadu $\mathrm{R}$ nepřesahuje $0,13 \%$.

Při odhadu poloměru $\mathrm{R}=500 \mathrm{~m}$ a vzdálenosti průsečíků do $5 \mathrm{~m}$ (zvolená přípustná hodnota $0,01 \cdot R$ ), je chyba $\mathrm{v}$ odhadu $\mathrm{R}$ do $0,634 \mathrm{~m}$. Skutečný poloměr R nebude menší než 499,366 m.

Při odhadu poloměru $\mathrm{R}=50 \mathrm{~m}$ a vzdálenosti průsečíků do $0,5 \mathrm{~m}$ (zvolená přípustná hodnota $0,01 \cdot R$ ), je chyba $\mathrm{v}$ odhadu $\mathrm{R}$ do $0,0634 \mathrm{~m}$. Skutečný poloměr R nebude menší než 49,9366 m.

Pokud odhad poloměru R bude menší než skutečná vzdálenost mezi pozorovatelnou a výstř̌elnou rovinou, pak kružnice př́mku neprotne. Řešení těchto rovnic pak v reálném oboru neexistuje, existuje pouze v komplexním oboru, kdy každá ze souřadnic E a N má reálnou a imaginární složku. Tato skutečnost komplikuje použití efektivnějších iteračních metod, jako je metoda půlení intervalu (bisekce), metoda tětiv (regula falsi) atd.

\subsubsection{Metoda extrému funkce}

Po dosazení rovnice přímky (5) do rovnice kružnice (4), obdržíme závislost jedné osové souřadnice, $\mathrm{v}$ tomto př́padě $\mathrm{N}$ na poloměru kružnice $\mathrm{R}$

$$
\left(a_{C} \cdot N+b_{C}-E P\right)^{2}+\left(N-N_{P}\right)^{2}=R^{2},
$$

Po úpravách, přejde rovnice do tvaru

$$
N^{2}+2 \cdot \frac{\left(a_{C} \cdot b_{C}-a_{C} \cdot E_{P}-N_{P}\right)}{\left(a_{C}{ }^{2}+1\right)} \cdot N+\frac{\left(b_{C}-E_{P}\right)^{2}+N_{P}{ }^{2}}{\left(a_{C}{ }^{2}+1\right)}-\frac{R^{2}}{\left(a_{C}{ }^{2}+1\right)}=0 .
$$


Ke zjednodušení zápisu provedeme substituci:

a) $A=(-1) \cdot\left(\frac{a_{C} \cdot b_{C}-a_{C} \cdot E_{P}-N_{P}}{1+a_{C}{ }^{2}}\right)$,

Poznámka: Tento koeficient A rovnice (14) je současně souřadnice N průsečíku výstřelné roviny a kolmice procházející objektem P. Potom

$$
N_{P R}=A=(-1) \cdot\left(\frac{a_{C} \cdot b_{C}-a_{C} \cdot E_{P}-N_{P}}{1+a_{C}^{2}},\right.
$$

b) $C=\frac{\left(b_{C}-E_{P}\right)^{2}+N_{P}{ }^{2}}{1+a_{C}{ }^{2}}$.

Po provedení substituce členy A a C př́ejde rovnice (13) do tvaru

$$
N^{2}-2 \cdot A \cdot N+C-\frac{R^{2}}{\left(a_{C}{ }^{2}+1\right)}=0
$$

Rovnici upravíme a vyjádř́me $\mathrm{N}$ jako funkci $\mathrm{R}$

$$
(N-A)=\left(A^{2}-C+\frac{R^{2}}{\left(a_{C}{ }^{2}+1\right)}\right)^{\frac{1}{2}} .
$$

Po úpravách

$$
N=A+\sqrt{A^{2}-C+\frac{R^{2}}{\left(a_{C}^{2}+1\right)}} .
$$

Toto je rovnice N-tých souřadnic průsečíků výstřelné s kružnicí mající střed v souradnicích pozorovatelny, kde proměnná je R.

Pokud nalezneme nejmenší $\mathrm{R}$ větší než 0 , pro které platí tato rovnice, $\mathrm{v}$ reálném oboru, nalezli jsme minimální vzdálenost objektu od přímky výstřelné roviny, což odpovídá extrému funkce.

Vypočítáme extrém funkce rovnice (19), která je funkcí $\mathrm{R}\left(N=\mathrm{f}_{(\mathrm{R})}\right)$ s použitím 1. derivace.

1. derivaci funkce $N=\mathrm{f}_{(\mathrm{R})}$ podle proměnné $R$ je ve tvaru:

$$
N_{(R)}^{\prime}=\frac{1}{2} \cdot\left(A^{2}-C+\frac{R^{2}}{\left(a_{C}{ }^{2}+1\right)}\right)^{-\frac{1}{2}} \cdot 2 \cdot \frac{R}{\left(a_{C}{ }^{2}+1\right)} .
$$

První derivaci rovnice (20) položíme rovno 0,

$$
N_{(R)}^{\prime}=\frac{1}{2} \cdot\left(A^{2}-C+\frac{R^{2}}{\left(a_{C}{ }^{2}+1\right)}\right)^{-0,5} \cdot 2 \cdot \frac{R}{\left(a_{C}{ }^{2}+1\right)}=0 \text {. }
$$


Rovnici (21) upravíme a hledáme podmínky platnosti, které odpovídají extrému funkce.

$$
\frac{\sqrt{A^{2}-C+\frac{R^{2}}{\left(a_{C}{ }^{2}+1\right)}}}{A^{2}-C+\frac{R^{2}}{\left(a_{C}{ }^{2}+1\right)}} \cdot \frac{R}{\left(a_{C}{ }^{2}+1\right)}=0 .
$$

\section{Rovnice (22) se rovná 0 za těchto podmínek:}

a) $\left(a_{C}^{2}+1\right)=\infty$, nebo $\left(a_{C}^{2}+1\right)=-\infty$,

b) $R=0$,

c) $A^{2}-C+\frac{R^{2}}{\left(a_{C}{ }^{2}+1\right)}=\infty$, nebo $A^{2}-C+\frac{R^{2}}{\left(a_{C}{ }^{2}+1\right)}=-\infty$,

d) $\sqrt{A^{2}-C+\frac{R^{2}}{\left(a_{C}{ }^{2}+1\right)}}=0$.

\section{Rozbor podmínek, kdy rovnice (22) se rovná 0.}

a) $\left(a_{C}{ }^{2}+1\right)= \pm \infty$ když $a_{C}= \pm \infty$, kde $a_{C}=\operatorname{tg} \alpha_{C}$, pak $\alpha_{C}= \pm 90^{\circ}+k \cdot 180^{\circ}$.

Extrém je v případě, je-li směrník na cíl $90^{\circ}$, nebo $270^{\circ}$. Tento stav odpovídá zvláštnímu případu, kdy rovina výstřelné je rovnoběžná s osou E, což odpovídá největší možné vzdálenosti mezi středem kružnice a výstřelnou rovinou.

b) $\mathrm{R}=0$. Toto je nejmenší možný poloměr, kterého je možno dosáhnout. Tento stav nastane, leží-li objekt prrímo na výstřelné prrímce a odpovídá extrémní hodnotě nejmenšímu možnému poloměru $\mathrm{R}$. Podmínka $\mathrm{R}=0$, může být splněna ve třech prípadech:

- Objekt je přestřelován, nachází se na ose výstřelné přímky mezi body B (palebné postavení děla) a C (cíl).

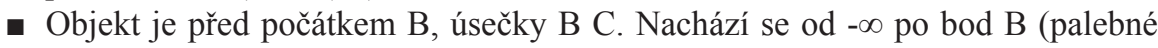
postavení děla). Objekt je za palebným postavením.

- Objekt je za koncem C úsečky B C. Nachází od bodu C po $+\infty$. Objekt je za cílem ve směru střelby děla.

Uvedená situace, kdy objekt $\mathrm{P}$ se nachází na výstřelné rovině, nastává v praxi jen ve zcela výjimečných př́ipadech.

c) $A^{2}-C+\frac{R^{2}}{\left(a_{C}{ }^{2}+1\right)}= \pm \infty$

U uvedené rovnice je řešení možné při splnění jedné z podmínek: 
1. $R=\infty$

To je největší možný poloměr, který protne přímku (ve dvou bodech) procházející rovinou výstřelné. Větší poloměr neexistuje. To však není poloměr, který hledáme.

$R^{2}=-\infty$

Řešení je pouze v komplexním oboru, to není poloměr, který hledáme.

2. $A^{2}= \pm \infty$

A je definováno podle vztahu (14) a po úpravě

$$
A=(-1) \cdot\left(\frac{a_{C} \cdot\left(b_{C}-E_{P}\right)-N_{P}}{1+a_{C}{ }^{2}}\right)
$$

Pak $A=\infty$, jestliže $N_{P}=\infty$, nebo $b_{C}-E_{P}=-\infty$. Při řešení není př́ímo vyjádřen poloměr R, jedná se o zvláštní př́pady, kdy jedna ze souřadnic pozorovatelny má $N_{P}=\infty$ či $E_{P}=\infty$ prípadně posunutí př́mky $b_{C}=\infty$, což je pro úlohu nepoužitelné.

Pro $A^{2}=-\infty$ nemá smysl úlohu řešit, protože řešení je v komplexním oboru.

3. $C= \pm \infty$

$C= \pm \infty$
C je definováno podle rovnice (16) ve tvaru $C=\frac{\left(b_{C}-E_{P}\right)^{2}+N_{P}{ }^{2}}{1+a_{C}{ }^{2}}$

I. $C=\infty$, jestliže $N_{P}^{2}=\infty$ nebo $\left(b_{C}-E_{P}\right)^{2}=\infty$.

Zde opět není prímo vyjádřen poloměr R, jedná se tedy o zvláštní př́ipady, kdy jedna ze souřadnic pozorovatelny je $N_{P}= \pm \infty$, případně $E_{P}= \pm \infty$ nebo posunutí výstřelné $b_{C}$ v ose E je v nekonečnu.

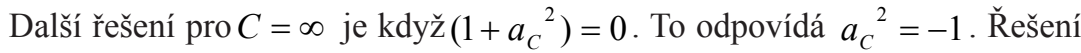
je v komplexním oboru, a proto nemá smysl toto řešení dále analyzovat.

Poznámka:

II. $C=-\infty$ pak musí platit $N_{P}{ }^{2}=-\infty$, nebo $\left(b_{C}-E_{P}\right)^{2}=-\infty$

Řešení těchto př́ípadů je možné, pokud souřadnice cíle nebo palebného postavení, prŕípadně obojí jsou v komplexním oboru. Proto tento prrípad nemá význam dále analyzovat.

d) $\sqrt{A^{2}-C+\frac{R^{2}}{\left(a_{C}{ }^{2}+1\right)}}=0$

výraz umocníme, provedeme úpravy, a vyjádř́me R,

$$
R=\sqrt{\left(C-A^{2}\right) \cdot\left(1+a_{C}{ }^{2}\right)} \text {. }
$$


Toto je řešení úlohy. Udává nejmenší poloměr kružnice, která se protne (dotkne) $\mathrm{s}$ přímkou výstřelné roviny $\mathrm{v}$ jednom bodě. Je to nejmenší vzdálenost mezi objektem a výstřelnou rovinou.

Po dosazení substitučních členů A a C (14) a (16) do rovnice (27) a po úpravě máme rovnici proměnné $\mathrm{R}$ ve tvaru

$$
R=\sqrt{\left(b_{C}-E_{P}\right)^{2}+N_{P}{ }^{2}-\frac{\left(a_{C} \cdot b_{C}-a_{C} \cdot E_{P}-N_{P}\right)^{2}}{1+a_{C}{ }^{2}}} .
$$

Výpočet $\mathbf{E}$ souřadnice průsečíku $\mathbf{P R}\left(E_{P R}\right)$ se provede, když do rovnice př́mky procházející cílem (5), se vloží rovnice průsečíku $N_{P R}(14)$. Po úpravách je souřadnice E průsečíku ve tvaru

$$
E_{P R}=\frac{\left(a_{C}\right)^{2} \cdot E_{P}+a_{C} \cdot N_{P}+b_{C}}{1+a_{C}^{2}} .
$$

Kontrola výpočtu vzdálenosti objektu od výstřelné roviny $\mathbf{R}$ se provede pomocí souřadnicových rozdílů, když do rovnice (30) dosadíme hodnoty spočítané z rovnic (29) a (14)

$$
\mathrm{R}=\sqrt{\left(\mathrm{E}_{\mathrm{P}}-\left(\mathrm{E}_{\mathrm{PR}}\right)^{2}+\left(\mathrm{N}_{\mathrm{P}}-\left(\mathrm{N}_{\mathrm{PR}}\right)^{2}\right.\right.} .
$$

\section{Závěr}

Uvedená metoda výpočtu $\mathrm{R}$ - vzdálenosti objektu od výstřelné roviny - je sestavena pro případ, kdy nejsou vypočítány jiné pomocné hodnoty odpovídající délkám, úhlům, případně směrníkům. Uvedenou úlohu autor článku obecně vyřešil i jinými způsoby, a to pomocí trojúhelníků, pomocí kolmice $\mathrm{z}$ bodu $\mathrm{P}$ na prímku $\mathrm{BC}$, otáčením bodů $\mathrm{C}$ a P okolo bodu B, otáčením celé souřadné soustavy kolem bodu B. Popsané odvození metody průsečíku přímky a kružnice vyžaduje vypočítat nejmenší počet pomocných proměnných. Metoda je vhodná zvláště v těch př́padech, kdy jsou známy jen souřadnice bodů $\mathrm{B}, \mathrm{P}, \mathrm{C}$ a nebyly provedeny žádné výpočty, které se používají pro řešení palebných úloh.

V prŕípadě sestavení automatizovaného systému, kde jsou vloženy všechny body odpovídající charakteru bodů $\mathrm{P}$, může hypoteticky nastat prrípad, kdy je vypočítaná vzdálenost $\mathrm{R}$, od objektu k výstřelné rovině velmi malá až nulová a nemusí nastat porušení bezpečnostních pravidel. Rovnice totiž nedetekuje zvláštní případ, kdy objekt P (nekryté cvičící jednotky, jednotky v obrněné technice, místa velení, sklady, obydlená místa, prípadně pozorovatelna ...) je za bodem B (za palebným postavením děla baterie) zamířeného do směru střelby. V tomto případě objekt $P$ není přestřelován. Dálka na cíl z objektu $\mathrm{P}\left(d_{C}\right)$ je v pak větší než dálka topografická $\left(D_{T}{ }^{C}\right)$ měřená z děla na cíl.

Pro lepší pochopení aplikace odvozených vzorců je na další straně uveden vzorový príklad. 


\section{Príklad}

\section{ZADÁNí}

Při návrhu cvičení střelby z děl je výstřelná nejblíže objektu-pozorovatelně, když zkrácené pravoúhlé souřadnice palebného postavení krajního děla baterie, cíle a objektu (pozorovatelny) v metrech mají tyto hodnoty:

$\mathrm{B}\left(\mathrm{N}_{\mathrm{B}}, \mathrm{E}_{\mathrm{B}}\right)=\left(\mathrm{N}_{\mathrm{B}} 32672 ; \mathrm{E}_{\mathrm{B}} 47164\right)$ - palebné postavení děla baterie,

$\mathrm{C}\left(\mathrm{N}_{\mathrm{C}}, \mathrm{E}_{\mathrm{C}}\right)=\left(\mathrm{N}_{\mathrm{C}} 45492 ; \mathrm{E}_{\mathrm{C}} 47124\right)$ - cíl,

$\mathrm{P}\left(\mathrm{N}_{\mathrm{P}}, \mathrm{E}_{\mathrm{P}}\right)=\left(\mathrm{N}_{\mathrm{P}} 43981 ; \mathrm{E}_{\mathrm{P}} 47734\right)$ - objekt (pozorovatelna).

Pro realizaci provedení paleb v rámci cvičení zkontrolujte, zda objekt není přestřelován (je splněna podmínka, že nejmenší vzdálenost mezi objektem a výstřelnou rovinou je větší než $500 \mathrm{~m})$.

\section{ŘEŠENÍ}

Vzdálenost objektu P od výstř̌elné roviny - R.

\section{Směrnice př́mky výstřelné roviny}

$$
\begin{aligned}
& a_{C}=\operatorname{tg} \alpha_{C}=\frac{\Delta E_{(B-C)}}{\Delta N_{(B-C)}}=\frac{E_{C}-E_{B}}{N_{C}-N_{B}} \\
& a_{C}=\operatorname{tg} \alpha_{C}=\frac{47124-47164}{45492-32672} \\
& a_{C}=-0,00312012480499220[-]
\end{aligned}
$$

\section{Poznámka:}

Ze spočítaného směrníku př́mky, při zahrnutí kvadrantu, ve kterém je řešeno $\operatorname{tg} \alpha_{C}$, lze určit směrník na cíl $\mathrm{a}_{C}=\operatorname{arctg}\left(a_{C}\right)$.

Spočítaná hodnota směrníku na cíl je $\alpha_{\mathrm{C}}=359^{\circ} 49^{\prime} 16,43^{\prime \prime}=59-97,02$ dc.

\section{Posunutí přímky}

$$
\begin{aligned}
& b_{C}=E_{\mathrm{C}}-a_{C} \cdot N_{\mathrm{C}} \\
& b_{C}=47124-(-0,00312012480499220) \cdot 45492 \\
& b_{C}=47265,9407176287[\mathrm{~m}]
\end{aligned}
$$

\section{Kontrola výpočtu posunutí přímky}

$$
\begin{aligned}
& b_{B}=E_{\mathrm{B}}-a_{C} \cdot N_{\mathrm{B}} \\
& b_{B}=471674-(-0,00312012480499220) \cdot 32672 \\
& b_{B}=47265,9407176287[\mathrm{~m}]
\end{aligned}
$$


Výpočet posunutí př́mky byl proveden správně, protože platí

$$
b_{C}=b_{B}=47265,9407176287[\mathrm{~m}]
$$

Rovnice přímky výstřelné, která prochází body B (palebné postavení děla) a C (cíl), je $E=a_{C} \cdot N+b_{C}$

$$
E=(-0,00312012480499220) \cdot N+47265,9407176287 \text {. }
$$

Výpočet substitučního členu $A=N_{P R}$ (odpovídá souřadnici $N_{P R}$, průsečíku kolmice $\mathrm{z}$ objektu $\mathrm{P}$ a rovině výstřelné přímky.

$$
\begin{aligned}
& A=(-1) \cdot\left(\frac{a_{C} \cdot b_{C}-a_{C} \cdot E_{P}-N_{P}}{1+a_{C}{ }^{2}}\right) \\
& A=(-1) \cdot\left(\frac{(-0,00312012480499220) \cdot 47265,9407176287-(-0,00312012480499220) \cdot 47734-43981}{1+(-0,00312012480499220)^{2}}\right) \\
& A=N_{P R}=43979,1114521095[\mathrm{~m}]
\end{aligned}
$$

\section{Výpočet substitučního členu $C$}

$$
\begin{aligned}
& C=\frac{\left(b_{C}-E_{P}\right)^{2}+N_{P}{ }^{2}}{1+a_{C}{ }^{2}} \\
& C=\frac{(47265,9407176287-47734)^{2}+43981^{2}}{1+(-0,00312012480499220)^{2}} \\
& C=1934528607,50993[\mathrm{~m}]
\end{aligned}
$$

\section{Vzdálenost objektu od výstřelné roviny.}

$$
\begin{aligned}
& R=\sqrt{\left(C-A^{2}\right) \cdot\left(1+a_{C}{ }^{2}\right)} \\
& R=\sqrt{\left(1934528607,50993-43979,1114521095^{2}\right) \cdot\left(1+(-0,00312012480499220)^{2}\right)} \\
& \mathrm{R}=605,282545159481[\mathrm{~m}]
\end{aligned}
$$

Výpočet souřadnice $\mathbf{E}$ průsečíku kolmice z objektu $\mathrm{P}$ a roviny výstřelné přímky.

$$
\begin{aligned}
& E_{P R}=a_{C} \cdot N_{R}+b_{C} \\
& E_{P R}=(-0,00312012480499220) \cdot 43979,1114521095+47265,9407176287 \\
& E_{P R}=47128,720401085550[\mathrm{~m}]
\end{aligned}
$$


Kontrola výpočtu vzdálenosti $\mathbf{R}$ objektu od výstřelné roviny pomocí souřadnicových rozdílů

$$
\begin{aligned}
& \mathrm{R}=\sqrt{\left(\mathrm{E}_{\mathrm{P}}-\mathrm{E}_{\mathrm{PR}}\right)^{2}+\left(\mathrm{N}_{\mathrm{P}}-\mathrm{N}_{\mathrm{PR}}\right)^{2}} \\
& \mathrm{R}=\sqrt{(47734-47128,7204010855)^{2}+(43981-43979,1114521095)^{2}} \\
& \mathrm{R}=605,282545159481[\mathrm{~m}]
\end{aligned}
$$

Kontrola výpočtu proběhla úspěšně, protože i druhým zpo̊sobem výpočtu byla spočítána stejná hodnota vzdálenosti objektu od výstřelné.

\section{Závěr}

Objekt je od výstřelné roviny vzdálen $605 \mathrm{~m}$. To je více než $500 \mathrm{~m}$, a proto hodnotíme, že při střelbě objekt není přestř̌elován. V případě přestřelování musí být objekt od cíle dále, než je bezpečná vzdálenost, jejíž výpočet je uveden v předpise Vševojsk 2-9 Bezpečnostní opatření při výcviku.

Souřadnice bodu průsečíku PR, mezi kolmicí a výstřelnou rovinou, jsou před zaokrouhlením na metry $N_{P R}=43979,1114521095$ [m], $E_{P R}=47128,72040108550[\mathrm{~m}]$.

\section{Poznámka k textu:}

[1] Zde je nutno zmínit, že objekty typu „postavení vševojskové jednotky“ (př. opěrný bod mechanizované čety), místa velení apod., jsou rozměrově větší objekty a nelze tudíž pracovat se souřadnicemi středu daného objektu, ale musí být použita souřadnice nejkrajnějšího bodu objektu vzhledem k vytyčené výstřelné. U malorozměrových objektů, typu pozorovací stanoviště, je možno jeho souřadnici považovat za tu nejkrajnějš́i.

\section{Použitá literatura:}

MO ČR. Bezpečnostni opatřeni při výcviku. Vševojsk -2-9. Praha: DP-SRDS-OS MO, 2011, 79 s. BARSCH, Hans-Jochen. Matematické vzorce. Praha: SNTL, 1971, 580 s.

Mám pro vás na závěr ještě kontrolní otázku, jestlipak víte, které instituci, nebo organizaci lidé v České republice nejvíc věří?

No, podle posledního výzkumu veřejného mínění je to Armáda České republiky.

$Z$ rozhovoru s Ing. Františkem Mičánkem (brig. gen. v zál.), ředitelem Centra bezpečnostních a vojensko-strategických studií UO,

Co vy na to? Český rozhlas Brno, 8. 5. 2014, dostupné na http://prehravac.rozhlas.cz/audio/3119747. 